\title{
DESTRUCTION OF THIAMINE BY CERTAIN FUNGI
}

\author{
KENJI OZAWA, HIDEO NAKAYAMA AND RYOJI HAYASHI \\ Department of Microbiology, Yamaguchi Medical School, Ube
}

(Received October 5, 1957)

\begin{abstract}
Yonezawa and Aoki (i) examined the thiamine-decomposing activity of cell suspensions of 96 strains of yeast-like fungi isolated from the oral cavity and found that, while Candida albicans, of which there were 62 strains, failed to show any thiaminase activity, the $\mathrm{C}_{4}$ strain forming abnormal colonies had a strong thiaminase activity. Another strain, $A_{9}$, was also found to have thiaminase activity, though weaker than $\mathrm{C}_{4}$. Biological studies on the properties of these fungi showed that the former closely related to Trichosporon cutaneum and the latter to Candida parapsilosis, but differing in some respects they were postulated to be new species (2-5). Liao (6), on the other hand: found no thiaminase activity in the cultures of 100 strains belonging to Candida. Hayashi et al. $(7,8)$ observed thiamine-decomposing activity of the cell suspensions of several strains belonging to Candida, and Ogata (9) detected the activity in the supernatant fluid of the destroyed cells of Candida albicans, C. pseudotropicalis and C. crusei.

The present authors have studied the thiaminase activity of the cell suspensions of 52 known stock strains of yeast-like fungi and found the majority to have thiaminase activity, though different in potency.
\end{abstract}

\section{EXPERIMENTAL}

\section{Materials and Methods}

\section{Strains Tested.}

The majority of the strains were obtained from the Institute for Fermentation, Osaka and a part from the Nagao Institute, Tokyo. $\mathrm{C}_{4}$ strain of Yonezawa and Aoki was kindly supplied by Dr. Yonezawa.

\section{Method of Cultivation.}

Each strain was cultured on Sabouraud plates, and incubated at $25^{\circ}$ for 48 hours.

3. Determination of Thiaminase Activity.

Cells grown on plates were harvested and a suspension containing $0.05 \mathrm{~g}$ wet cells per $\mathrm{ml}$ of water was prepared. $0.5 \mathrm{ml}$ phosphate buffer $(\mathrm{pH} 6.5)$ and $1 \mathrm{ml}$ thiamine solution $(3 \mathrm{r} / \mathrm{ml})$ were added to $4 \mathrm{ml}$ of the suspension, and the mixture was incubated at $45^{\circ}$ for 2 hours. As a control, the cell suspension was heated at $80^{\circ}$ for 20 minutes and treated further as described above. After incubation, the residual total thiamine was measured. The difference between 
the total thiamine recovered from the control mixture and that of the main mixture was taken as the quantity of thiamine decomposed.

\section{Optımum $p H$.}

For testing the optimum $\mathrm{pH}$ for decomposing thiamine, $1.0 \mathrm{ml}$ of thiamine solution $(3 \mathrm{r} / \mathrm{ml})$ and $0.5 \mathrm{ml}$ of buffer were added to $4 \mathrm{ml}$ of the cell suspension. Acetate buffer was used for $\mathrm{pH}$ range 4.5-5.5, and phosphate buffer 5.5-8.0. After the reaction at $45^{\circ}$ for 2 hours, the remaining thiamine was measured. The thiamine decomposed was calculated from the difference in the remaining vitamin between the control and main test.

\section{Optimum Temperature.}

To $4.0 \mathrm{ml}$ of cell suspension were added $1.0 \mathrm{ml}$ thiamine solution $(3 \mathrm{r} / \mathrm{ml})$ and $0.5 \mathrm{ml}$ phosphate buffer $(\mathrm{pH} 6.5)$. Each mixture was incubated for 2 hours at $10,20,30,40,50,60,70$, and $80^{\circ}$, respectively and the remaining thiamine was determined in each case.

\section{Measurement of Thiaminase Potency.}

The cell suspension was assumed to be the enzyme solution and the thiaminase potency $\left(Q^{\prime}\right)$ of representative strain was measured as follows according to Fujita (11). Three varying dilutions of the cell suspension were made and those showing a decomposition of 50 per cent or more of the added thiamine during one hour at their optimum $\mathrm{pH}$ and temperature were selected. From the per cent decomposition thus selected the thiaminase potency, $Q^{\prime}, i . e ., \gamma$ thiamine decomposed per $\mathrm{g}$ wet cells was calculated.

\section{Determination of Thiamine.}

On completion of the reaction, the $\mathrm{pH}$ of the reaction mixture was adjusted to 4.5 with $N / 10 \mathrm{HCl}$, and the mixture was heated for 20 minutes at $80^{\circ}$ in order to stop the thiaminase activity and at the same time to extract thiamine from the cells. Then $1.0 \mathrm{ml}$ of 6 per cent Takadiastase solution, pretreated with kieselguhr to remove the existing thiamine, was added. After hydrolysis at $45^{\circ}$ for 1 hour and $\mathrm{pH} 4.5$, the whole was centrifuged for 30 minutes at 3000 $\mathrm{rpm}$ and the supernatant was passed through a zeolite column to remove disturbing fluorescing substances. Thiamine was then measured by a cyanogen bromide method with a fluorophotometer.

\section{Test for Thiamine Disulfurylase.}

The mixture was heated for 15 minutes at $80^{\circ}$ following completion of the reaction and then treated with cysteine according to the method of Tamaki $e$ al. (13). The total thiamine after cysteine treatment was compared to that without cysteine treatment.

\section{Results}

\section{Decomposition of Thiamine by Fungi.}

The decomposition of thiamine by the 52 strains examined is summarized in Table I, from which it can be seen that thiamine is destroyed in the majority of them. Since the total thiamine was measured, the action of "thiamine phosphorylase" (16) is excluded and since no rise in thiamine was found after adding cysteine in the strains showing the disappearance of more than 30 per cent of the thiamine added, this cannot be attributed to "thiamine disulfurylase" (12). 
TABLE I

Thiamine Decomposition of 52 Strains Tested

\begin{tabular}{|c|c|c|c|}
\hline \multicolumn{2}{|c|}{ Strains Tested } & \multirow{2}{*}{ No. ${ }^{a}$} & \multirow{2}{*}{$\begin{array}{c}\text { Thiamine decomposition } \\
\text { per cent }\end{array}$} \\
\hline & & & \\
\hline Torulopsis & miso & 0449 & 42 \\
\hline , & , & 0445 & 52 \\
\hline$"$ & ", & 0443 & 44 \\
\hline$"$ & $"$ & 0442 & 45 \\
\hline$"$ & , & 0438 & 46 \\
\hline$"$ & ", & 0440 & 49 \\
\hline , & 9 & 0450 & 46 \\
\hline$"$ & , & 0446 & 65 \\
\hline$"$ & $"$ & 0436 & 16 \\
\hline , & $"$ & 0444 & 45 \\
\hline$"$ & $"$ & 0437 & 67 \\
\hline$"$ & , & 0447 & 27 \\
\hline$"$ & uvae & 0452 & 36 \\
\hline$"$ & colliculosa & 0381 & 43 \\
\hline$"$ & mandshurica & 0443 & 21 \\
\hline$"$ & lactica & 0432 & 33 \\
\hline ", & aeria & 0377 & 9 \\
\hline$"$ & xylinus & 0454 & $\overline{7} 4$ \\
\hline , & sake & 0435 & 14 \\
\hline " & candida & 0405 & 0 \\
\hline Torulaspora & rosei & 0428 & 69 \\
\hline "' & "' & 0430 & 83 \\
\hline ", & " & 0431 & 74 \\
\hline ", & delbrücki & 0426 & 52 \\
\hline ", & ", & 0427 & 43 \\
\hline , & fermentat $i$ & 0422 & 56 \\
\hline Korula & dematia & 5371 & 91 \\
\hline , & succhari & 4440 & 75 \\
\hline$"$ & lactis & 0399 & 81 \\
\hline , & , & 0400 & 89 \\
\hline " & "' & 0398 & 89 \\
\hline Cryptococcus & albidus & 0378 & 80 \\
\hline , & , & 0434 & 26 \\
\hline ", & luteolus. & 0411 & 5 \\
\hline$"$ & laurentii & 0384 & 19 \\
\hline$"$ & neoformans & 0545 & 35 \\
\hline " & glabrata & 0005 & 60 \\
\hline Trichosporon & cutaneum & 0174 & 82 \\
\hline Kloeckera & africana & 0177 & 0 \\
\hline$"$ & apiculata & 0175 & 0 \\
\hline$"$ & $"$ & 0150 & 0 \\
\hline " & " & 0151 & 0 \\
\hline Rhodotorula & rubula & 0416 & 7 \\
\hline " & minuta & 0387 & 83 \\
\hline$"$ & flava & 0407 & 5 \\
\hline$"$ & mucilaginosa & 0001 & 16 \\
\hline$"$ & logissima & 0386 & 17 \\
\hline$"$ & mucilaginosa & 0002 & 15 \\
\hline$"$ & glutinis & 0414 & 0 \\
\hline "' & gracilis & 0559 & 0 \\
\hline , & species & 0415 & 40 \\
\hline Kloechera & species & 0153 & 16 \\
\hline
\end{tabular}

a All the figures are the strain numbers of the Institute for Fermentation, Osaka.

The reduction of thiamine determined is therefore assumed to be due to the decomposition of thiamine. Samples which decomposed more than 50 per cent 
of $3 ;$ thiamine added included, among the fungi belonging to Saccharomycetaceae, 5 of the 6 strains of Torulaspora, and, among those belonging to Pseudosaccharomycetaceae, 3 of the 20 strains of Torulopsis, 5 of the 5 strains of Torula, 2 of the 6 strains of Cryptococcus, 1 of the 9 strains of Rhodotorula and the one strain of Trichosporon. Aside from Kloeckera which showed on thiamine decomposition and Trichosporon of which the number of samples tested was small, a definite difference ${ }^{1}$ in the activity of thiamine decomposition was found among four Genera, i.e., Torulopsis, Torulaspora, Crptococcus and Rhodotosula. The thiaminase potency was, if arranged in order of decreasing activity, Torula, Torulaspora, Torulopsis, Cryptococcus and Rhodotorula, the average percentage decomposition being $85,62.8,38.7,37.5$ and 20.3 , respectively. For the following experiments, four species having relatively intensive thiaminase activity, i.e., Trichosporon cutaneum 0174, Torula lactis 0398, Torulopsis xylinus 454 and Cryptococcus albidus 0378, were used and their activities were compared with that of $\mathrm{C}_{4}$ strain.

\section{Optimum $p H$.}

As shown in Fig. 1, the optimum $\mathrm{pH}$ for thiamine decomposition of Trichosporon cutaneum 0174, Torula lactis 0398, Cryptococcus albidus 0378 and the $\mathrm{C}_{4}$ strain was found to be 6.0. At pH 4.5, the activity failed to be dectected in

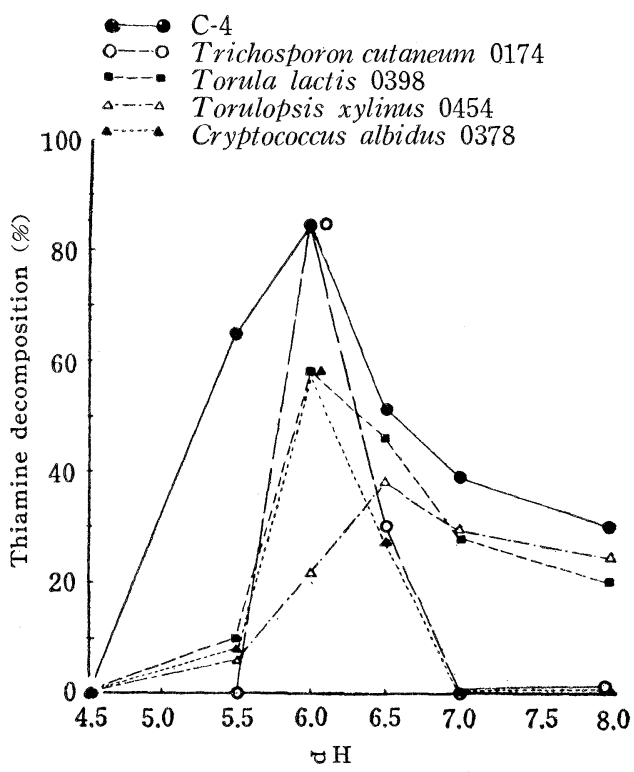

Fig. 1 Effect of $p H$ on Thiamine Decomposition by Cell Suspensions

Reaction system consisting of $1 \mathrm{ml}$ of thiamine solution containing $3.0 \gamma, 0.5 \mathrm{ml}$ buffer solution and $4.0 \mathrm{ml}$ cell suspension, was incubated at $45^{\circ}$ for $2 \mathrm{hr}$.

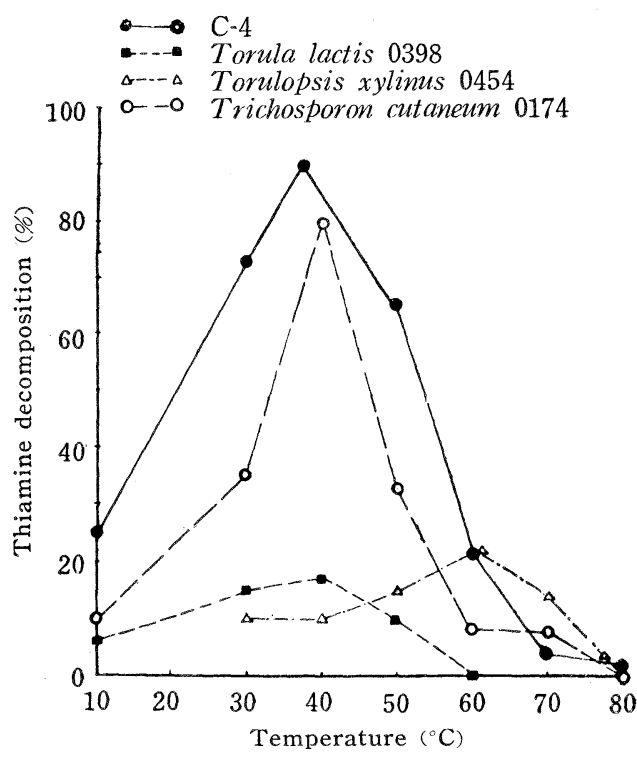

Fia. 2 Effect of Temperature on Thiamine Decomposition

Reaction system consisting of $1.0 \mathrm{ml}$ thiamine solution containing $3.0 \gamma, 0.5 \mathrm{ml}$ buffer solution ( $\mathrm{pH} 6.5$ ) and $4.0 \mathrm{ml}$ cell suspension, was incubated at $45^{\circ}$ for $2 \mathrm{hr}$.

\footnotetext{
${ }^{1}$ Ratio of unbiased estimates of variance, $0.82>\mathrm{F}_{41}^{4}(0.01)$
} 
any of the strains. But at $\mathrm{pH} 8.0$, a moderate activity was noted with the

TABLE II.

Thiaminase Potency of Several Strains Tested

\begin{tabular}{lc}
\multicolumn{1}{c}{ Strain tested } & Thiaminase potency $\left(Q^{\prime}\right)$ \\
\hline $\mathrm{C}_{4}$ & 146.0 \\
Cryptococcus albidus 0378 & 44.5 \\
Trichosporon cutaneum 0174 & 30.5 \\
Torua lactis 0398 & 22.8 \\
Torulopsis xylinus $0454^{\text {Candida crusei } 7492^{a}}$ & 14.5 \\
${ }^{a}$ Received from the Nagao Institute, Tokyo
\end{tabular}
exception of Trichosporon and Cryptococcus. On the other hand, Torulopsis xylinus 0454 was somewhat different, the optimum $\mathrm{pH}$ being 6.5 .

\section{Optimum Temperature.}

The results in Fig. 2 shows that the optimum temperature at $\mathrm{pH} 6.0$ for thiamine decomposition of $\mathrm{C}_{4}$, Trichosporon cutaneum 0174 and Torula lactis 0398 was found to be $40^{\circ}$, and any variation from this temperature resulted in decrease, whereas in the case of Torulopsis xylinus 0454 , the optimum was $60^{\circ}$, definitely higher than the others.

\section{Thiaminase Potency.}

The results given in Table II show that the activity of $\mathrm{C}_{4}$ strain is markedly higher than the others.

\section{Thiamine disulfurylase.}

Strains showing thiamine decomposition of more than 30 per cent were examined but thiamine disulfurylase was not detected.

\section{DISCUSSION}

It has been shown that the thiamine-decomposing action of $\mathrm{C}_{4}$ strain isolated by Yonezawa et al. is not due to thiamine disulfurylase, the decomposition products being hydroxymethyl-pyrimidine and thiazole moiety. It has also been found that neither base exchange reaction nor thiamine phosphorylation takes place, showing that the enzyme belongs to thiaminase II (17). Yonezawa et al. (15), however, failed to demonstrate thiaminase activity in 62 strains of Candida albicans which they isolated, though some strains of Candida have been reported to decompose thiamine $(9,14)$.

The author have tested 52 known stock strains of fungi and found that the added thiamine was more or less decomposed in the majority of cases. The action was demonstrated neither to be due to thiamine phosphorylase nor thiamine disulfurylase. It is thermolabile and has an optimum $\mathrm{pH}$ and temperature. These findings lead to the conclusion that the thiamine was decomposed by thiaminase.

\section{SUMMARY}

52 known stock strains of yeast-like fungi were tested for thiaminase activity and the following results were obtained.

1. Of the 51 strains tested, 16 (30 per cent) decomposed more than 50 per cent, 9 (18 per cent) $30-50$ per cent, while 27 (52 per cent) less than 30 per cent of the thiamine added at $\mathrm{pH} 6.5$ and $45^{\circ}$ in 2 hours in the presence of $3 \gamma$ thiamine. 
2. The thiaminase activity of representative strains, Trichosporon cutaneum 0174, Torula lactis 0398, Torulopsis xylinus 0454, Cryptococcus albidus 0378 and $\mathrm{C}_{4}$ strain of Yonezawa and Aoki was studied and found that the optimum $\mathrm{pH}$ was 6.0 and the optimum temperature $40^{\circ}$. Torulopsis xylinus, however, differed in that the optimum $\mathrm{pH}$ was 6.5 and the optimum temperature $60^{\circ}$.

3. Determination of the thiaminase potency according to Fujita showed that $\mathrm{C}_{4}$ strain had the highest value, 146. Cryptococcus albidus 0378 had the value, 44.5 and Trichosporon cutaneum $0174,30.5$, only one-fourth that of $\mathrm{C}_{4}$.

4. It is concluded that thiaminase is widely distributed in yeast-like fungi.

\section{REFERENCES}

1. Yonezawa, K., and Aoki, F., Vitamins 7, 600 (1954).

2. Yonezawa, K., and Aoki, F., ibid. 7, 601 (1954).

3. Yonezawa, K., and Aoki, F., ibid. 10, 130 (1956).

4. Yonezawa, W., Aoki, F., Ota, M., Nishio, K., and Matsumoto, K., J. Vitaminol. 3, 39 (1957).

5. Nishio, K., Vitamins 13, 94, 99 (1957).

6. Liao, M., ibid. 7, 600 (1954).

7. Hayashi, R., Shimomura, F., and Ogata, J., ibid. 9, 164 (1955).

8. Hayashi, R., ibid. 10, 470 (1956).

9. Ogata, J., Anual Meeting of the Sixth Japanese Pharm. Soc. (1954).

10. Ozawa, K., and Hayashi, R., Vitamins 10, 302 (1956).

11. Fujita, A., Nose, Y., and Kuratani, K., ibid. 6, 233 (1953).

12. Yasuda, T., ibid. 7, 17 (1953).

13. Tamaki, T., and Nose, Y., J. Vitaminol. 1, 185 (1955).

14. Jacobsohn, K., and Rosado, J. M., Compt. Rend. Soc. Biol. 18, 1454 (1952).

15. Aoki, F., Vitamins 9, 48 (1955).

16. Fujita, A., Kaminishi, K., Tashiro, T., Yamazaki, K., Suganuma, J., and Kishida, T., Kitasato Arch. Exp. Med. (Japanese). 22, 127 (1949).

17. Fujita, A., Nose, Y., and Kuratani, K., J. Vitaminol. 1, 1 (1954). 